\title{
ROBERT L. DETTERMAN (1919-1990)
}

Robert L. (Buck) Detterman, a highly respected and wellknown Alaskan geologist, died of cancer in Sunnyvale, California, 7 May 1990, at the age of 71 . His career in Alaska spanned a period of 42 years.

Born in Green Springs, Ohio, on 20 April 1919, he graduated from Green Springs High School in 1937 and received a B.A. degree in geology from Miami University, Ohio, in 1941. Detterman served as a meteorologist in the U.S. Army Air Force during World War II, stationed in Cordova and Attu, Alaska. In 1947 he joined the U.S. Geological Survey (USGS), Alaska Geology Branch, Navy Oil Unit, NPR No. 4. His first Alaskan assignment was studying Cretaceous rocks along the Nanushuk River on the North Slope. This was the beginning of a long, devoted, rewarding career in Alaskan geology.

Detterman was well known for his biostratigraphic studies of the Triassic through Tertiary age sediments throughout arctic and south-central Alaska and the Alaska Peninsula. He was also considered an authority on glaciation for the North Slope and the Alaska Peninsula. He wrote or coauthored more than 113 publications and maps. Several finished manuscripts still await publication by the USGS.

Because of his large bibliography, only a few of his more important publications will be mentioned here. He was the first to publish in detail the multiple stages and glacial advances in the Sagavanirktok-Anaktuvuk rivers region of the North Slope. This publication is USGS Circular 289, 1953. These stages are named the Anaktuvuk, Sagavanirktok, Itkillik and Echooka and are tentatively assigned the ages of pre-Wisconsin through late Wisconsin. In USGS Professional Paper 303-D, 1961, these glacial studies were enlarged upon and include detailed maps of the Sagavanirktok and Shaviovik rivers region.

Another important paper is the "Geology of the Chandler River Region, Alaska” (USGS Professional Paper 303-E, 1963). As senior author, he mapped and described in considerable detail the Lower and Upper Cretaceous sediments of the region. Here he describes and breaks down the Lower Cretaceous Nanushuk Group and the Upper Cretaceous Colville Group rocks into marine and non-marine facies and formations. Included in this paper is a discussion of the marine Lower Cretaceous Grandstand Formation, which is the producing horizon in the Umiat Oil Field and in the National Petroleum Reserve-Alaska.

In 1966 he was senior author of a paper on the Jurassic sediments of the Alaska Peninsula. This paper is entitled "Geology of the Iniskin-Tuxedni Region, Alaska" (USGS Professional Paper 512). Through detailed stratigraphic investigations, which included laborious fossil collecting, he was able to conclude that a composite section of over 26000 feet of Jurassic sediments is present in the region. This is considered to be one of the thickest Jurassic sections in the world.

From 1969 through 1974, Detterman returned to the North Slope and eastern Brooks Range, concentrating on Mesozoic and Tertiary studies. Besides his detailed stratigraphic studies on the Post-Carboniferous rocks, he also assisted in regional field mapping of the older rocks. During this time he redefined the Sadlerochit Formation, changing it to the Sadlerochit Group. The Sadlerochit is the main producing oil

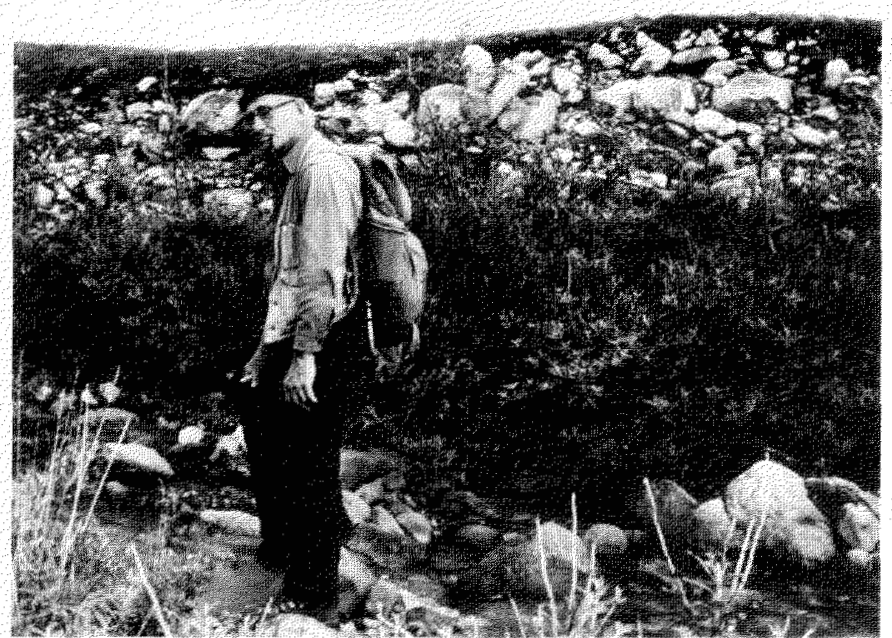

Detterman in June 1988 in the Arctic National Wildlife Range. (Photo by John Kelley, USGS.)

and gas horizon of the Prudhoe Bay Field. It was this work that made him so widely known among the North Slope geologists. This work is described in a paper for which he is senior author, "Post-Carboniferous Stratigraphy, Northeast Alaska" (USGS Professional Paper 886, 1975). This paper describes in detail the sedimentary rock units from Permian age through Tertiary.

After the 1974 field season in northern Alaska, he resumed his work on the Alaska Peninsula. In 1988, Detterman spent his last field season on the North Slope, studying the Triassic, Jurassic and Cretaceous sediments in the Arctic National Wildlife Range for the Alaska Geology Branch of the USGS. This was his last field season on his beloved North Slope.

During field seasons in the early years of his career, most of the work was arduous and was done by boat and foot traverse, long before helicopters came into general use.

Detterman belonged to the Geological Society of America, American Association of Petroleum Geologists, Geological Society of Alaska, Geological Society of Washington, American Association for the Advancement of Science, American Association of Quaternary Environment, California Academy of Science and the Arctic Institute of North America, which he joined in 1950 . He was a Registered California Geologist.

He was an invited speaker at many national geological seminars and symposiums, sharing his Alaskan work.

Detterman was a kind, easy-going, well-liked and respected man, but stood for what he believed in. He was a devoted husband and father. He is survived by his wife, Janice Scott Detterman, daughter, Linda, son, Mark, and three grandchildren.

Needless to say, Buck Detterman will be greatly missed by his numerous close friends and colleagues. His outstanding work on the North Slope and the Alaska Peninsula will be referenced for many years to come.

Marvin D. Mangus 1045 E. 27th Avenue Anchorage, Alaska 99508, U.S.A. 